\title{
CHARACTER BUILDING: ARE EFL TEACHERS READY? (VOICES FROM LANGUAGE CLASSROOMS)
}

\author{
Retno Wiyati \\ STKIP Pasundan, Indonesia \\ Email: retno_wiyati@yahoo.com \\ First Received: August 2019 \\ Final Proof Received: September 2019
}

\begin{abstract}
Character building education in classroom contexts is nowadays gaining a lot more attention than in the past as a way to provide solution to the social misbehavior that students often conduct outside classroom and even school levels. This is in line with the new curriculum of 2013 in which "Pendidikan nasional berfungsi mengembangkan kemampuan dan membentuk watak serta peradaban bangsa yang bermartabat....peserta didik agar menjadi manusia yang beriman dan bertakwa kepada Tuhan yang Maha Esa, berakhlak mulia,sehat, berilmu, cakap, kreatif, mandiri, dan mejadi warga negara yang demokratis serta bertanggung jawab (Suherdi, 2013). This indicates that character building education is very important in producing students who have a strong religious character as well as a good attitude to make them not only succeed academically in school but also in their social life. This study is thus aimed at finding out the aspects of characters that teachers and students need to possess, the teachers' role in promoting character education in the classrooms, and the importance of character education to enhance students' learning activities. This study involves several teachers and students of different classes from some English learning institutions. The preliminary study revealed that teachers do not have a significant role in emphasizing character building in the classrooms and that most students are not fully aware of the importance of character education in enhancing their learning.
\end{abstract}

Keywords: Character education, teachers' role, classrooms and social life

\section{INTRODUCTION}

With the introductions of violence, crimes and other misconducts both from the media such as television, internet, newspaper, movies, tabloids, etc. and from the public displays of several misconducts committed by the respected members of the House of Representatives, conflicts and violence such as student brawls often appear and are seen as common scenes in Indonesia. Based on the conditions, the government through the 2013 curriculum re-introduces and re-inforces the vital role of character education in school life.

Character education in school life is one attempt to redeem the misconducts that students are involved in both in school zone and out of school zone. This character education is emphasized at school life since school is the learning center for Indonesian generations in which they can not only gain academic achievement but also moral values which will enable them not only to succeed academically but also morally and to prepare them how to adjust themselves well in the society once they finish their school years.

Since character education is implemented in school life, all school components must be ready to embrace the concept. In this case, teachers are the focal point of character education since teachers are the ones who deal with the teaching activities both in the classrooms and out of the classrooms. They are also the ones who take the biggest responsibilities of the students' achievement as well as the students' character displays. 
Teachers need to be equipped with adequate knowledge and the know-how to implement character education in their teaching processes. Teachers also need to have important roles in order that they can successfully implement the character education in their classrooms.

Regarding the issue above, the researchers are interested in investigating the readiness of the EFL teachers in Indonesian contexts in terms of character education within their classroom zones, what characters are mostly re-inforced and how they implement them.

\section{The Definition of Character (Education)}

There are some definitions on characters presented here which are drawn from different sources. The first definition on character is "The particular combination of qualities in a person or things" (Press, 2005). The second one is taken from Oxford Advanced Learner's Dictionary stating that character is "(a) mental or moral qualities that make a person, group, nation, etc. different from others" (Hornby \& Crowther, 1998). It can be inferred from both definitions that character is what set people, things, group or nation apart and that character can be a combination of mental or moral qualities. Other definitions are extracted from Thomas B. Macaully in which he proposes that "The measure of a man's real character is what he would do if he knew he would never be found out" In other words we can say that even when no one is looking or finding out, we can still try to do what is best for us and other people based on the mental and moral qualities. Bertkowitz (1997) cited in in (Suherdi, 2013) defines character as another dimension of human morality and serves as a group of individual psychological characters which influence his or her ability to act with or without moral. Other definition on character comes from Thomas Lickona who states that "Character functions as inner disposition that allows a person to respond well when faced with moral situations"(Cited in (Suherdi, 2013)).

From those definitions above, it can be concluded that characters have something to do with human's moral values and how he or she implements them in his or her life and society based on the good moral values that do not violate other people's well-being.

\section{Why Character Education?}

As previously discussed, character education in Indonesian educational system is gaining more popularity nowadays by the launching of the new 2013 curriculum. Character education in Indonesian schools is needed to be emphasized and implemented in order to shape new generations which can display good conducts in and out of the school zones based on the religious teachings as well as good mental and moral values.

This section will try to present some important aspects of the inclusion of character education at schools extracted from (Laura \& Gurley, 2020) which include first, kids might not be getting it at home. They may have all the loving parents they have at home, but not all parents know how to pass on their love through character education at home. Some parents might be too busy to do that so that by giving their kids all the luxurious things might be enough to show their love to their kids. They do not have ample time to just sit with their kids and do the talking about character education. Schools and teachers, on the other hand, where kids spend most of their time away from parents and that teachers are the ones who interact most with the kids at school and therefore, they have all the responsibilities and time to nurture the kids with a good moral and character teachings. Second, character education builds relationship. At school in the classrooms, students do not only interact with other students on lessons and subjects but also they maintain a social and personal relationship with other students and even with the 
teachers. This condition is when they share stories, what they think and act with each other and thus teachers can effectively pass on character education in a more natural atmosphere. Third, character education creates positive school environments. Character education at schools can strengthen the relationship between students and other students as well as between students and the teachers. Once students have the positive understanding of what good characters and morals are, conditions become conducive and it allows them to be engaged positively with other students and teachers. The last, character education is easy. Teachers do not need to spend lots of hours on research and lesson plans on how to teach the characters. Teachers can start from simple things such as telling his or her own experience or somebody else's experience which have certain moral values in it and discuss them with the students. This can take as much as five or ten minutes only and by doing this teacher can also engage students in speaking and listening activities.

Other important reasons of why character education is important to be implemented at school can also be extracted from the Michigan State Board of Education as follows:

The Michigan State Board of Education believes that there are two important reasons to teach character education in public schools. First, the well-being of a democratic society requires the civic engagement of ethical citizens. Character education must be a deliberate and long-term effort by families, schools, and community partners to help young people to understand, care about, and act upon shared ethical values. Secondly, character education helps students learn. Qualities such as caring, responsibility, and respect for oneself and others, fairness, trustworthiness, citizenship, and self-restraint promote a healthy, safe, and supportive learning environment that promotes the primary mission of the school, which is to educate ("Michigan State Board of Education Policy on Integrating Mental Health in Schools," 2004).

The extracts above indicate that the teaching of characters in schools is important and that character education should be implemented deliberately by all the relevant figures both in schools, in the community and at home and in the long term to ensure that the students can have good moral values and can help students to learn better. So, schools do not just equip students with cognitive intelligence but also with social and good ethical knowledge.

Those four reasons are not the only resources for us to refer to character education in the classrooms, especially in Indonesian EFL contexts. There are many other aspects that we can take into considerations in relation with the teaching of characters in the classrooms.

\section{Character Education in the 2013 Curriculum}

As the focal point of this research is regarding the character education in the Indonesian EFL contexts, the researchers have somewhat the obligation to discuss a little bit how this character education is outlined in the curriculum. To start with, the 2013 curriculum has four main qualities outlined in it that students have to obtain throughout their schooling years. Those main points are: 1 . The group of religious/spiritual students: have to be religious and to obey rules from God; 2 . The group of moral/character: have a good morale, healthy, independent, and become a democratic and responsible citizen; 3 . The group of knowledge: be knowledgeable; 4. The group of creativity: Be smart, be creative (Suherdi, 2013).

From the four main points above, we can see in point number two that the 2013 curriculum places a strong emphasize on character/moral aspects. It can be inferred that the ultimate goals of the students stated in the 2013 curriculum are not only to have a 
good academic skills/knowledge as is stated in point number four but also to have a good quality of characters/morals. Thus, once they finish their study at school, they will become a complete individual who are smart in terms of academic achievement as well as in terms of their moral and character achievement.

\section{The Role of EFL Teachers in Promoting Character Education in the Classrooms}

The core of this research is on EFL teachers applying character education in their classrooms. How they implement characters in their teaching and learning activities with their students. Thus, the discussion on their roles in the process is important to be discussed here. As teachers may have different roles in their classrooms, it is important to find out how their roles fit with the processes of implementing character education in their classrooms.

There are some roles of EFL teachers that can be drawn regarding the implementation of character education in the classrooms. One of the roles is stated by Dr. Shaileigh Page, a passionate educator-numeracy, ICT and Education Philosophy who implements the role of encouraging students with good choices and provide consequences for those choices that are not so good. She does that by applying "character cards" in which she would give rewards and punishment for students who act or do not act based on the good choices of characters that she has discussed previously. The rewards and punishments are so that students do not feel superior or even inferior in doing the consequences (Shaileigh, 2013).

Another role is through the teaching of characters explicitly by the medium of proverbs (Sadtono, 2011). In this case, teachers choose and use the proverbs which have specific moral and character values to be discussed with the students in the class. The researcher further explained that through the use of proverbs, teachers have the roles of improving the students' English proficiency as well as internalizing the values instilled by the proverbs (Sadtono, 2011).

Last but not least is that based on the preliminary study on character building previously conducted, teachers of EFL have to be the role model themselves. Teachers in the study stated that they always display the good characters that students need to imitate. It has the implication that teachers do not always use words to teach characters to the students but they also have to be able to become the role models of the characters. Regarding the roles of the teachers in promoting character education, there are at several roles that teachers can have in the classrooms such as the role of caregivers, models and mentors, teachers can also treat students with love and respect, can set a good example, can support pro-social behavior and correct actions that are inappropriate. The teachers can also serve as people who create a community of moral who can help students to respect and care about each other so that students can feel valued by others.

Based on the insights above, the researchers are interested in investigating the EFL teachers' readiness in applying character education in their classrooms as well what the students have to say about character education in their classrooms. The researchers would try to find out the aspects of characters implemented and how the teachers promote the implementation of those characters in the classrooms.

\section{METHOD}

\section{Respondents}

The venue of the study is in Bandung in several formal and non-formal learning institutions. The location is in Bandung because this is where the researchers live and the researchers assumed that they will not get difficulties in cost, time and distance in order for the researcher to collect the data. This study is conducted from the periods of March 
to June 2013 and this study involves several English teachers as well as students form several formal and non-formal learning institutions. The teachers are all English teachers teaching in different formal and non-formal learning institutions. The sample teachers consist of 13 teachers. Those teachers were chosen because most of them know the researchers well so that they can provide an easy access for the researchers to collect data from them. The sample students consist of 47 students from several learning institutions. They were chosen by the researchers because represent the purpose of this study which is to investigate the implementation of character education in the EFL classrooms.

\section{Data Collection Techniques}

The data is collected by giving out questionnaires both for the teachers as well as the students. The questionnaires are in the forms of open questions and there are five questions for each of the questionnaires. The questionnaire for the teachers consists of five questions which include their understanding on character education in general, the importance of character education in enhancing students' learning, characters that they teach or emphasize in their classrooms, their on-hands teaching experience or techniques of the characters that they choose to teach or emphasize and their opinion on the explicit implementation of character education in their classrooms. The questionnaire for students, on the other hand, consists of four open-ended questions which include their choices of characters which can enhance their learning, their understanding on which characters do their teacher emphasize in their classrooms, their understanding on how their teacher implements the character education in their classroom and their opinion on the importance of character education in their classroom. The data gathered form both questionnaires for the teachers and the students are then analyzed and are compared and then described qualitatively.

\section{FINDINGS AND DISCUSSION \\ Teachers' Questionnaire}

There are five open ended questions in the teachers' questionnaire. The questions include the aspects of 1 . Teachers' understanding on character education in general, 2. The importance of character education in enhancing students' learning based on teachers' view, 3. The kinds of characters teachers apply or emphasize in the classrooms, 4. Teachers on-hand experience or techniques in implementing the characters in their classrooms, 5. Teachers opinion on the explicit teaching of characters in the classrooms. The following table is the findings from the teachers' questionnaire based on the five aspects above:

Table 1. Teachers' questionnaire results

\begin{tabular}{|c|c|c|}
\hline Aspects of questionnaire & Findings & Percentage \\
\hline $\begin{array}{l}\text { Teachers' understanding on character } \\
\text { education in general }\end{array}$ & $\begin{array}{l}\text { a. As a good teaching on moral values } \\
\text { b. Help students' in improving their } \\
\text { potentials }\end{array}$ & $\begin{array}{l}85 \% \\
15 \%\end{array}$ \\
\hline $\begin{array}{l}\text { The importance of character education } \\
\text { in enhancing students' learning based } \\
\text { on teachers' points of view }\end{array}$ & $\begin{array}{l}\text { a. Helping students understanding their role } \\
\text { b. Providing students with good values for } \\
\text { their future and their interactions with the } \\
\text { society } \\
\text { c. Creating convenient classroom } \\
\text { atmosphere }\end{array}$ & $\begin{array}{l}38 \% \\
38 \%\end{array}$ \\
\hline $\begin{array}{l}\text { The kinds of characters teachers apply } \\
\text { or emphasize in the classrooms }\end{array}$ & $\begin{array}{ll}\text { a. Discipline } \\
\text { b. Honesty } \\
\text { c. Responsibility } \\
\text { d. Tolerance } \\
\text { e. Respect }\end{array}$ & $\begin{array}{l}77 \% \\
69 \% \\
85 \% \\
46 \% \\
46 \% \\
\end{array}$ \\
\hline
\end{tabular}




\begin{tabular}{llll}
\hline & f. & Independence & $38 \%$ \\
\hline $\begin{array}{l}\text { Teachers' on-hand experience or } \\
\text { techniques in applying the characters }\end{array}$ & a. & $\begin{array}{l}\text { Give good and bad consequences to the } \\
\text { students }\end{array}$ & $62 \%$ \\
& b. & Through co-operative learning & $38 \%$ \\
\hline Teachers' opinion on explicit teaching & a. & Agree(explicitly) & $46 \%$ \\
of characters in the classrooms & b. & Disagree(implicitly) & $46 \%$ \\
& c. & Both (explicitly and implicitly) & $8 \%$ \\
\hline
\end{tabular}

The table above shows the results of the teachers' questionnaire as follows: in aspect number one which is teachers' understanding on character education in general, $85 \%$ of them showed the understanding of as good moral values so that students can possess good manners such as being responsible in their own learning, helping others with the learning, following classroom rules to becoming a responsible Indonesian citizen. $15 \%$ of the teachers stated that character education is one way to help students' improving their potentials in the learning to ensure their success. The second aspect of the questionnaire is about the importance of character education in enhancing students' learning, teachers came up with the answers of helping students understand their roles in the classrooms (38\%) meaning that once students understand what their roles are which are to study, to gain knowledge, to create projects. They will know how to improve their own learning; providing students with good values for their success in the future and in the society $(38 \%)$ so that they can interact well both with the teachers and with other students in the classrooms, they can handle difficulties without conflicts and violence both in and out of school zones and can display good conducts in the society once they finish their schooling years. In answering the third question which is about the kinds of characters teachers apply or implement in the classrooms, the character of discipline was chosen 10 times since teachers really expect students to come on time to class and to collect their work and or projects on time. Honesty was chosen 9 times adding that teachers often find students cheating during the test and copying other people's work especially in writing projects. Thus, they need to implement the character of honesty often. The majority of the teachers chose the character of responsibility as the most important one (chosen 11 times). They argued that students need to be taught responsibility so that when they commit mistakes, they admit that and can try to amend their mistakes. Tolerance and respect characters each were chosen 6 times by the teachers. They only emphasize those characters in situations when they need to show their tolerance when there are differences of ideas and opinions in the classrooms or when the teachers are talking, they have to show their respect. Independence was chosen only five times by the teachers. They explained that for some reasons, students need to be independent such as when doing the test, doing some projects, having to bring dictionaries to the class, etc. When asked on their on-hand experience of implementing those characters, $85 \%$ of the teachers expressed that they provide good and bad consequences for the students. For examples when the students come late or do not collect their homework on time, teachers would punish them by either not permitting them to join the session or by reducing their scores. As for the students who can show good conducts in the class, teachers would give praises to them either through words or scores or even rewards in the forms of simple gimmicks. The last question was regarding teachers' opinion on the explicit teaching of characters in their classrooms. In terms of teaching explicitly, $46 \%$ of the teachers agreed on it. Some argued that students really need to get the education on characters through explanation from their teachers so that they can really grasp and apply the values in their life, others argued that students often lose their focus easily and that they need to be reminded again and again regarding the moral values which are important in enhancing their learning. Interestingly, $46 \%$ of the teachers chose to teach the characters implicitly in which some of them argued that 
characters need habitual actions, they must be built within ourselves so the teaching of characters will flow naturally, teachers can also become role models of the good characters for the students to see and imitate, others expressed that teachers can teach characters through stories, movies, songs which have certain moral values in them and through group discussions. Only $8 \%$ of them chose to teach the characters both explicitly and implicitly. They argued that there are some characters that can be addressed explicitly to the students such as to come on time and not to cheat on the test and especially when students are not aware of the characters embedded in the teaching and learning processes. They also expressed that there are other characters that need to be implicitly taught to the students through role models and through telling stories, songs, personal experience that have certain values which can be discussed and applied in the classrooms.

From the questionnaire results and elaboration above, we can infer that teachers of EFL have already have the knowledge and the readiness to apply or implement character education in their teaching and learning processes in the classrooms. It can be seen from their responses when asked about the kinds of characters in their classrooms and also the techniques they do in the classrooms to implement those characters. Teachers also show their awareness that characters play a very important roles in the life of the students both when they still in the schooling years as well as when they are already engaged in the worlds of work in the workplaces and in the community. Teachers show their awareness by stating their responses when asked about the importance of character education in enhancing students' learning. They came up with different and thoughtful answers regarding the roles of character education in enhancing students' learning. The last and yet the most important aspect of this research is regarding the roles of the teachers in implementing character education in their classrooms. Teachers, in this case showed their readiness by expressing that they can implement character education explicitly, implicitly or both in their classrooms. This aspect is very important since according to Aristotle cited in Berkowitz and Bier:

"All adults involved with children either help or thwart children's growth and development, whether we like it, intend it or not. "The inescapable fact is this: as adults involved intimately with children, educators cannot avoid "doing" character education. Either intentionally or unintentionally, teachers shape the formation of character in students - simply by association-through positive or negative example. Character education is thus not optional in the school-it is inevitable, and therefore merits intentional focus and priority status in the school (Berkowitz \& Bier, 2005).

Meaning that teachers are the focal point of character education in the classrooms either explicitly or implicitly and teachers also can be the agent of change in which teachers try to shape the formation of character in students through positive or negative examples.

\section{Students' Questionnaire}

As for the students, there are four open-ended questions in the questionnaire. The four questions include the aspects of: 1 . The kinds of characters students need to enhance their learning; 2. The kinds of characters teachers implement in the classrooms; 3. Teachers' techniques in implementing the characters, and 4. Students' opinion on the explicit teaching of characters in their classrooms. The following table shows the recapitulation of the result of the students' questionnaire: 
Table 2. Students' questionnaire result

\begin{tabular}{|c|c|c|c|}
\hline & Aspects of Questionnaire & Findings & Percentage \\
\hline \multirow[t]{8}{*}{1.} & \multirow{8}{*}{$\begin{array}{l}\text { The kinds of characters students } \\
\text { need to enhance their learning. }\end{array}$} & a. $\quad$ Discipline & $85 \%$ \\
\hline & & b. Honesty & $17 \%$ \\
\hline & & c. Responsibility & $10 \%$ \\
\hline & & d. Tolerance & $10 \%$ \\
\hline & & e. Diligence & $59 \%$ \\
\hline & & f. Persistence & $4 \%$ \\
\hline & & g. Self-confidence & $15 \%$ \\
\hline & & h. Active & $30 \%$ \\
\hline \multirow[t]{7}{*}{2.} & The kinds of characters teachers & a. Discipline & $100 \%$ \\
\hline & implement in their classrooms. & b. Honesty & $45 \%$ \\
\hline & & c. Responsibility & $47 \%$ \\
\hline & & d. Tolerance & $45 \%$ \\
\hline & & e. Diligence & $9 \%$ \\
\hline & & f. Self-confidence & $4 \%$ \\
\hline & & g. Active & $4 \%$ \\
\hline \multirow[t]{4}{*}{3.} & Teachers' techniques in & a. By explicit instructions & $55 \%$ \\
\hline & implementing the characters. & b. By becoming a role model & $11 \%$ \\
\hline & & $\begin{array}{l}\text { c. By telling stories and } \\
\text { personal experience }\end{array}$ & $11 \%$ \\
\hline & & d. By giving punishment & $19 \%$ \\
\hline & Students' opinion on the explicit & a. $\quad$ Agree (explicit teaching) & $94 \%$ \\
\hline & teaching of characters in the & b. Disagree (implicit teaching) & $4 \%$ \\
\hline & classrooms. & c. Both (Explicitly and & \\
\hline & & Implicitly) & $2 \%$ \\
\hline
\end{tabular}

The table above shows that when students are asked the kinds of characters that can help enhancing their learning, $85 \%$ of them chose the character of discipline as the most important character that they think would help them learn better in English subject. When asked why, they came up with the answer that if they are not disciplined, the teacher would not allow them to join the class and this according to them will hamper their chance to master the subject well. The second most chosen character is diligence with 59\% students chose this character. They have the opinion if they are diligent in following the sessions with the teacher, in doing homework and in classroom participations, the teachers will give them good credits that will boost their confidence (15\% chose this character) in learning the subject. As for the aspect of honesty, only $17 \%$ chose this character. They think that honesty is not the most important character in enhancing their learning. Students also argued if they are active (14\%) in the classroom discussions and activities, they can master the subject well. The students chose responsibility and tolerance with $10 \%$ only. While the least chosen character is persistence $(10 \%)$.

On the second aspect of the kinds of characters that teachers implement in their classrooms, $100 \%$ students stated that their teacher implements the character of discipline in their English classroom. $45 \%$ of them stated the character of honesty, $47 \%$ on responsibility, tolerance with $45 \%$, diligence $9 \%$, self-confidence and active with each $4 \%$. This reveals that in contrast with the characters students choose to have to enhance their learning in which they focus only on discipline and diligence, the teachers, on the other hand, bring into class the characters that they think will have a big impact on the students' success both in learning as well as in the society. The teachers try to emphasize the importance of being discipline by not coming late to class, by meeting the deadline of tasks, homework and or projects, being honest in showing their capabilities by not cheating and doing plagiarism or copying other people's works, being responsible on 
their own learning and goals in the future, having tolerance to others in terms of learning co-operatively, being diligent in classroom activities and discussions, having a selfconfidence to help them learn better and being active in all classroom activities to help them experience the learning of the subject. When again the students were asked why they only focused on the two characters previously mentioned, they came up with the answer that those two characters are the ones that can actually help them learn the subject better.

The third aspect of the questionnaire which is teachers' techniques in implementing the characters, the students came up with the techniques of explicit instructions (55\%) in which the teachers explicitly instruct students to possess good characters every time problems regarding characters came up in the classrooms for example when students came late, teachers would stop the discussion about the lesson and would then talk about the importance of being discipline. $11 \%$ stated that their teachers became role models of good characters for the students to imitate by showing their discipline, their responsibility in teaching schedule and activities. $11 \%$ of them also stated that their teachers often told stories that have moral values in them and discussed the moral values together or they shared their own personal experience which were related to certain moral values. $19 \%$ of the students surprisingly came up with the answer of giving punishment. They explained that their teachers liked to give punishment if they violated any of the good characters that teachers implement in the classrooms. The punishment ranged from not being able to join the session to making a speech in English in the classrooms spontaneously.

The last aspect of the questionnaire was about the students' opinion on the explicit teaching of characters in the EFL classrooms by the teachers. $94 \%$ of them preferred their teachers to explicitly teach characters in their classrooms because they argued that they need to be reminded explicitly again and again by their teachers about good characters that they need to have in order to be successful. If the teachers do not do that, they stated that they would not understand what characters they need to possess. $4 \%$ of them chose to disagree with the explicit teaching of characters in their classrooms. They stated that they preferred their teacher to become role models of the good characters so that they can imitate the good characters from their teacher. $2 \%$ expressed that they preferred their teachers to both explicitly teach the good characters by explaining to them the importance of the characters as well as to implicitly teach the good characters by becoming role models or by discussing stories or personal experience with certain values or characters to discuss and implement.

From the results of the students' questionnaire above, it can be inferred that students are mostly familiar with the characters of discipline and diligence and they put low emphasize on other important characters such as honesty, responsibility, tolerance, persistence, self-confidence as well as being active. This explains why lots of teachers complain about students' attitude in the test such as cheating and also students' works/projects in which they do several copying from other people's work without feeling of guilty. While in the out of school zones, the members of the community often complain and condemn the acts of students being involved in brawls and other activities involving violence. This is related to the characters that they adhere to mostly. They think that by becoming discipline such as by coming on time to class, by collecting their projects on time or by always attending the sessions are enough for them to achieve good results in the subject and to prepare them for a better future. These are not enough since in order to be academically as well as socially successful, students need to adhere to a complete set of good characters that teachers, schools and community share and emphasize. 


\section{CONCLUSION}

The aim of this research is to investigate the readiness of EFL teachers in implementing character education in their classrooms and how students embrace the idea of character education in their classrooms to enhance their learning academically and socially. The data was gathered through giving out two kinds of questionnaires for the teachers as well as for the students. The results so far indicated that character education is very important to be implemented in the classrooms as can be seen by the students' responses in which they perceived good characters can lead them to be successful in their learning and can help them to have good quality of conducts when they are in the workplace and in the community. The teachers also have the same opinion in which they stated that the implementation of character education in the classrooms can help students understand their roles as students, help them to understand their potentials and can shape students to have good moral qualities. Regarding the implementation of the character education outlined in the new curriculum of 2013, the result of this research would hopefully provide a strong base for the government, the ministry of education and other related authority figures in education to formulate the rules and policies regarding the kinds of characters that must or should be implemented by the schools and other learning institutions, what the roles of the school board of management are regarding the implementation of the character education and most importantly what roles the teachers should have in their attempts of implementing the character education in their classrooms since teachers have the biggest responsibilities in assuring the success of the students not only academically but also socially. This study would also hopefully provide insights for teachers as well as other language practitioners who take the same interests on character education. They can be able to at least get the information on the real portraits of character education in schools especially in Indonesian EFL contexts.

\section{REFERENCES}

Berkowitz, M. W., \& Bier, M. C. (2005). . What Works in Character Education: A research driven guide for educators. Washington DC: Character Education Partnership.

Hornby, A. S., \& Crowther, J. (1998). Oxford Advanced Learners' Dictionary. (J. Crowther, Ed.) (5th ed.). Oxford University Press.

Laura, \& Gurley, S. (2020). The Inclusion of Character Education at Schools. Retrieved from https://www.the-teachers-lounge.com/

Michigan State Board of Education Policy on Integrating Mental Health in Schools. (2004). Retrieved from https://www.michigan.gov/documents/mde/MHPolicySBE_FINAL_310961_7.pdf

Press, C. U. (2005). Cambridge Advanced Learners' Dictionary(CALD). (E. Walter, Ed.) (2nd ed.). Cambridge University Press.

Sadtono, E. (2011). Character Building: Killing Two Birds with One Stone. 58th TEFLIN International Conference: Language Teaching and Character Building, 817-833.

Shaileigh. (2013). Character - doing the right thing when no one is looking. Retrieved from https://drshaileighpage.wordpress.com/2013/04/24/

Suherdi, D. (2013). Buku Pedoman Penyelenggaraan Pendidikan Profesi Guru Bahasa Inggris: Buku Ajar Pemantapan Kompetensi Akademik 3.1. Bandung: Celtic Press. 


\section{APPENDICES}

Appendix 1

CHARACTER BUILDING: Are EFL Teachers Ready?

(Voices from Language Classrooms)

\section{Teachers' Questionnaire}

Name

:

Level

PLEASE PROVIDE THOUGHTS FOR THE FOLLOWING QUESTIONS BASED ON YOUR CURRENT UNDERSTANDING AND EXPERIENCE.

1. What's your understanding on character education?

2. What importance do you think character education has in enhancing students' learning?

3. As a teacher, do you apply character education in your class? If yes, which of the followings characters do you teach? You may choose more than one or add others.
a. Discipline
b. Honesty
c. Responsible
d. Tolerance
e. Others:

4. Based on your choice(s) in no. 3, please give real examples based on your experience on how you teach your students those characters in your classroom.

5. In your opinion should you emphasize or teach characters explicitly in your classroom? Why/Why not? 
Appendix 2:

CHARACTER BUILDING: Are EFL Teachers Ready?

(Voices from Language Classrooms)

Name

Students' Questionnaire

Level

PLEASE PROVIDE ANSWERS FOR THE FOLLOWING QUESTIONS BASED ON YOUR CURRENT EXPERIENCE.

1. What kinds of characters do you think you need to possess to help you succeed in your learning?

2. Does your teacher teach you characters in your classroom? If yes, what kinds of characters does your teacher teach you? You may choose more than one option or add others.
a. Discipline
b. Honesty
c. Responsible
d. Tolerance
e. Others:

3. If your teacher teaches you any of the characters in question no. 2, how does your teacher do that? Please explain or give examples based on your experience in your class?

4. In your opinion should your teacher emphasize or teach characters explicitely in your classroom?Why/Whynot? 